\title{
Study on the Development of Industry of Internet of Things Based on Competitive GEM Model in Fujian Province
}

\author{
Jun $\mathrm{An} \mathrm{Di}^{1, \mathrm{a}}$, Hao $\mathrm{Li}^{2, \mathrm{~b}}$ \\ ${ }^{1}$ Department of Electronic Information Engineering, Minjiang University, Fuzhou, Fujian China 350121 \\ ${ }^{2}$ Straits Institute, Minjiang University, Fuzhou, Fujian China 350121
}

\begin{abstract}
Firstly, the basic theories of internet of things, competitive GEM model and industrial development in Fujian Province were studied in this paper. Then, the factors influencing the cultivation of industrial competitiveness of the internet of things was observed and finally the suggestions on enhancing the competitiveness of internet of things and strengthening the cultivation of talents of internet of things were put forward.
\end{abstract}

Key words:. internet of things, industrial development, Fujian, GEM model

\section{Current Situations of the Development of Internet of Things in Fujian Province}

As the third tide of the world information technology reform after the computer, internet and mobile communication networks, the internet of things has been included in national strategic emerging industries and begun to take shape. For example, Fujian Province has a basically completed industrial chain in sensor, network transmission and data processing and lots of enterprises with national advanced product $\mathrm{R} \& \mathrm{D}$ and application promotion appear in some field. According to the preliminary statistics, the annual sales revenue of the industry of internet of things was about RMB 10 billion Yuan in 2014, of which the revenue from sensor was RMB 2 billion Yuan, the revenue from transmission network was RMB 1 billion Yuan and the revenue from application software and system integration was RMB 7 billion Yuan. So far there have been more than 100 institutions and enterprises working on
R\&D, production, application and service of internet of things in Fujian Province and parts of technical research and development is advanced in China. For example, Fujian Province is leading in the R\&D of the field below: sensors, automatic control, electronic receipt, radio card reader, self-service terminal, middleware platform of operating system of internet of things and home network system. It has established three RFID application research centers and achieved preliminary results in the transformation of scientific and technological achievement. Besides, the application market is expanded continuously. The products of Fujian Province are widely used in China in the aspect of urban management, intelligent monitoring, food trace and water quality monitoring and its sensors have been exported to foreign markets. The 2D intelligent reading machine, various labels, smart cards, RFID reading equipment and network terminals have been widely used domestically. Since 2002, the communication

\footnotetext{
Notes: this project is funded by 2015 Fujian Provincial Science and Technology Planning Project (Project No. 2015R0067)

About the author: Di Jun-an (1960- ), male, Professor of the Department of electronics Minjiang University),

Research direction: information processing.E-mail: dmieorg@163.com

Li Hao (1980- ), male, lecturer and engineer of Minjiang University, doctoral graduate on information and communication engineering major in Wuhan University of Technology. Research direction: mobile information, electronic commerce, information communication. E-mail:eastlihao@163.com
} 
operators have started to customize the solutions to the internet of things, which integrate the data collection, transmission, processing and business management for industrial customers, such as "Megaeye", "Location Service" and security monitoring, and have accumulated rich experience in the operation of internet of things. Additionally, the technology of internet of things, such as RFID has been applied perfectly in the charge for entering the island and operation of express way. The communication network equipment is advanced. Fujian has constructed a domestically advanced information network system approaching the world advanced technology level. The high-speed wired and wireless broadband have spread all over the whole province, and $97 \%$ and $100 \%$ of villages have realized the wired and wireless internet, and the relevant indicators, such as popularizing rate of mobile phone and total number of wired broadband, website, netizen and domain name has ranked the fourth to sixth in China. Fujian is one of provinces to construct TD-SCDMA firstly in China, and has basically perfect thirdgeneration of mobile communication infrastructures and has the foundations and conditions to promote the application of extensive information network and wireless information technology more highly, deeply and largely along with the $3 \mathrm{G}$ network transformation construction of telecom CDMA2000 and Unicom WCDMA.

\section{Empirical Study on the Competitiveness of the Industrial Cluster of Internet of} Things Based on Gray Incidence Assessment Method

In the opinion of Porter, the industrial cluster refers to the gathering of the enterprises, research institutes and colleges which influence and interact mutually in certain industry. The industrial cluster is a kind of organization and management mode for regional economy. In the wake of the success of the Silicon Valley in the United States, Bangalore in India, EmiliaRomagna in Italy, Hsinchu in Taiwan, Tsukuba in Japan and Zhongguancun in China, lots of states and regions have great expectations for the industrial cluster as a successful mode to development local economy. The industrial cluster can bring about a large number of competitive advantages for enterprises in the cluster, such as the direct competitive advantage in economy of cost advantage, product difference advantage, marketing advantage and competitive advantage in market, as well as bring about the formal and informal network forming the information of communicated enterprises in order to promote the non-direct economic competitive advantage of technical innovation and provide conditions for implicit and non-coding knowledge transfer and distribution inside the region. Studies show that enterprises in the cluster have stronger competitiveness than enterprises of the same kind and at the same stage outside the cluster, which attracts more scholars to study the competitiveness of industrial cluster. There are two methods: qualitative method and quantitative method in the "GEM" model to evaluate the competitiveness of the industrial cluster. Quantitatively, a kind of model to evaluate the competitiveness of industrial cluster, GEM model is concluded based on "groundings-enterprises-markets" by two Canadian scholars: Padma and Gibson on the basis of "Diamond Model" through many years of research. GEM model consists of "three elements and six factors", namely basic elements (including resource and facility), enterprise element (including supplier/relevant enterprises and manufacturer structure/strategic factor), market element (including local market and foreign market) (see Figure 1). GEM model is based on "three elements and six factors" mentioned above. In GEM model, the three elements are respectively groundings, market and enterprises and every element consists of two factors. The groundings contain facility factor and resource factor and the enterprise contains manufacturer structure/strategy and supplier and relevant enterprises. The market contains local market and foreign market, which is the demand element of industrial cluster. For the detailed meanings of "three elements and six factors", please refer to Table 1. The quantitative evaluation of GEM model is divided into three steps:

I. Factor evaluation. Every factor in every element will be given ten points in accordance 
with the world standard. 1 point indicates that the cluster develops badly in this aspect and in a similar fashion, 10 points indicates that the industrial cluster develops excellently in this aspect, has a world-class competitiveness and ranks the first in the world. For the detailed evaluation standard, please refer to Table 2.

II. Calculation of the point of "factor pair". In GEM model, factors in every element are believed to be replaceable. Thus the point of "factor pair" is the average value of the points of two factors, namely, PS (Pair Score) $=(\mathrm{D} 2 \mathrm{i}-$ $\mathrm{i}+\mathrm{D} 2 \mathrm{i}) / 2$. In the formula above, PS (Pair Score) represents the "points of factor pair", D2M represents $1^{\text {st }}$ factor corresponding to the $i^{\text {th }}$ element while $\mathrm{D} 2 \mathrm{i}$ represents $2^{\text {nd }}$ factor corresponding to the $i^{\text {th }}$ element. $i$ in the formula is 1,2 and 3.

III. Calculation of the total point of competitiveness of industrial cluster. This step is divided into two small steps. Firstly, the point of three "factor pairs" is transferred into linear score of industrial cluster. The formula is: $\mathrm{LCS}=\mathrm{ni}=1 \ldots 3(\mathrm{PS})=\mathrm{ni}=1 \ldots 3(\mathrm{D} 2 \mathrm{i}-1+\mathrm{D} 2 \mathrm{i}) / 2$ and in the formula LCS is short for Linear Cluster Score. It can be seen from the formula above that the linear score of the industrial cluster is the product of score of three factors and the score of six factors influencing the competitiveness of industrial cluster has equal effect on the score of the competitiveness of total industrial cluster. The low score of any factor will lead to low total score. Secondly, the score of LCS is transformed to make the final score 1000 scores (indicating the status that the score of each factor will be 10 score). The calculation formula is $\mathrm{GEM}=2.5$ ( $\mathrm{n} .=\mathrm{i} . . .3(\mathrm{D} 2 \mathrm{i}-$ $\mathrm{i}+\mathrm{D} 2 \mathrm{i}) / 2)^{2 / 3}$.

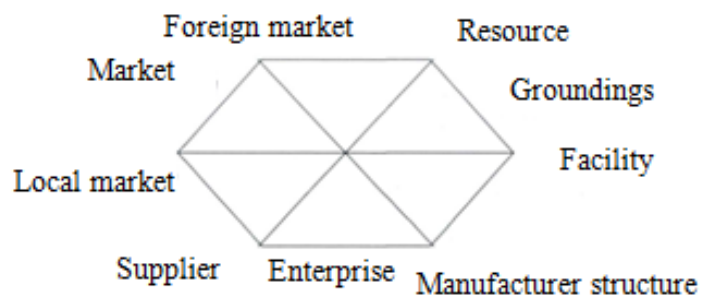

Figure 1 GEM model
Table Meaning of Elements and Factors of GEM Model

\begin{tabular}{|c|c|c|}
\hline Factor & Element & Meaning \\
\hline \multirow[t]{2}{*}{$\begin{array}{l}\text { Groundin } \\
\text { gs }\end{array}$} & Resource & $\begin{array}{l}\text { Refers to the resources inherent locally and formed later, such as } \\
\text { geographical position, natural resources, patent technology, financial } \\
\text { capital }\end{array}$ \\
\hline & Facility & $\begin{array}{l}\text { Refers to the hardware and software, such as road, port, pipe and } \\
\text { communication facility, software facility includes system arrangement, tax } \\
\text { policy, training institution, commercial environment, etc. }\end{array}$ \\
\hline \multirow[t]{2}{*}{ Enterprise } & $\begin{array}{l}\text { Supplier/releva } \\
\text { nt enterprise }\end{array}$ & $\begin{array}{l}\text { Refers to the articles and services purchased by enterprises in the cluster } \\
\text { in the industrial cluster. }\end{array}$ \\
\hline & $\begin{array}{l}\text { Manufacturer } \\
\text { structure/strate } \\
\text { gy }\end{array}$ & $\begin{array}{l}\text { Refers to the number, scale of enterprises in the industrial cluster, } \\
\text { production mode between enterprises, management mode and ownership } \\
\text { structure, etc. }\end{array}$ \\
\hline \multirow[t]{2}{*}{ Market } & Local market & $\begin{array}{l}\text { Refers to the local market of industrial cluster, or a provincial or regional } \\
\text { market, or a national market }\end{array}$ \\
\hline & Foreign market & $\begin{array}{l}\text { Refers to the market except fro local market, such as market outside the } \\
\text { province and foreign market, etc. }\end{array}$ \\
\hline
\end{tabular}

Table 2 Grade and Scoring Standard of Factors

\begin{tabular}{|lll|}
\hline Grade of factor & Scoring & Scoring standard \\
\hline Grade one & 10 scores & Very excellent and has world-class competitiveness \\
\hline Grade two & 9 scores & Excellent and has world-class competitiveness \\
\hline Grade three & 8 scores & Unique nationally \\
\hline Grade four & 7 scores & Has national competitiveness \\
\hline Grade five & 6 scores & Exceeds national average level \\
\hline Grade six & 5 scores & National average level \\
\hline Grade seven & 4 scores & Lower than national average level \\
\hline Grade eight & 3 scores & Has a certain gap with national average level \\
\hline Grade nine & 2 scores & Has a great gap with national average level \\
\hline Grade ten & 1 score & $\begin{array}{l}\text { Has the greatest gap with national average level and } \\
\text { seriously influences the enhancement of industrial cluster }\end{array}$ \\
\hline
\end{tabular}

Evaluation of the factors influencing the competitiveness of industrial cluster of internet of things in Zhongguancun, Wuhan Donghu, Wuxi New Zone and Fuzhou Hi-tech Zone

1. Data source and evaluation method

The original data of this evaluation is from "2014 Chinese Torch Statistical Yearbook", "2014 Chinese Statistical Yearbook", "Statistical Report of the $32^{\text {nd }}$ Chinese Internet Development Status", "2014 Zhongguancun Indicators", official website of Beijing Zhongguancun National Independent Innovative Demonstration Area (www.zgc.gov.cn), official website of Wuxi New Zone (www.wnd.gov.cn), government website of Wuhan Donghu Hi-tech Industrial Development Zone (www.wnd.gov.cn) and Fuzhou National Hi-tech Industrial Development Zone after sorting and calculation of the author.

It will be evaluated in gray incidence assessment method. The competitiveness of the industrial cluster of internet of things is affected by various factors. Because the data and information used for evaluation is limited, especially the extreme shortage of local data, the local industrial cluster of internet of things can be regarded as a gray system and the gray 
incidence assessment method can be used to evaluate its competitiveness with limited information, and then the competitiveness of industrial cluster will become clearer and clearer and is turned from gray to white through limited information. During the evaluation, as the representative variables of the competitiveness of industrial cluster, the net profit and total income of the industrial cluster will be the reference sequence and the factors of G2EM-CI, such as groundings, enterprise, markets, value chains, governments and interactions will be the comparison sequence for evaluation. For the detailed evaluation indicator and original value of indicator, please refer to Table 3 and Table 4.

Table 3 Factors, elements and indicators for evaluation

\begin{tabular}{|c|c|c|}
\hline \multirow[t]{2}{*}{ Enterprise } & $\begin{array}{l}\text { Supplier and } \\
\text { relevant } \\
\text { supporting } \\
\text { enterprises }\end{array}$ & $\begin{array}{l}\text { Total number of incubator and productivity promoting } \\
\text { center (unit: PCS) }\end{array}$ \\
\hline & $\begin{array}{l}\text { Enterprise } \\
\text { structure strategy } \\
\text { and competition }\end{array}$ & $\begin{array}{l}\text { Number of hi-tech enterprise (Unit: PCS), hi-tech } \\
\text { enterprise scale (total revenue/number of enterprise) } \\
\text { (Unit: RMB ten thousand Yuan/enterprise) }\end{array}$ \\
\hline \multirow[t]{2}{*}{ Market } & Local market & $\begin{array}{l}\text { Total of turnover of technical output and technical input } \\
\text { (Unit: RMB ten hundred) }\end{array}$ \\
\hline & Foreign market & Turnover of domestic technical contract \\
\hline Value chain & High end & $\begin{array}{l}\text { Number of adopted technical standard (including national, } \\
\text { international and industrial standard) (Unit PCS) }\end{array}$ \\
\hline Government & Planning & Planning or not ( 10 for yes and 1 for no) \\
\hline Interaction & $\begin{array}{l}\text { Production-univers } \\
\text { ity-research } \\
\text { Production-supply- } \\
\text { marketing }\end{array}$ & $\begin{array}{l}\text { Number of R\&D institutes in the cluster (including } \\
\text { colleges and universities, research institutes, } R \& D \text { center } \\
\text { of company, etc.) } \\
\text { Number of industrial association/alliance in the cluster }\end{array}$ \\
\hline $\begin{array}{l}\text { Competitivenes } \\
s \text { of industrial }\end{array}$ & $\begin{array}{l}\text { Net profit of } \\
\text { cluster }\end{array}$ & Net profit amount \\
\hline cluster & $\begin{array}{l}\text { Total revenue of } \\
\text { cluster }\end{array}$ & Total revenue amount \\
\hline
\end{tabular}

Table 4 Original data of evaluation indicator based on G2EM-CI model (2014)

\begin{tabular}{cccccccc}
\hline $\begin{array}{c}\text { Industrial } \\
\text { duster }\end{array}$ & $\begin{array}{c}\text { Technical } \\
\text { talent }\end{array}$ & $\begin{array}{c}\text { Authorize } \\
\text { d patent }\end{array}$ & Incubator & $\begin{array}{c}\text { Number of } \\
\text { enterprise }\end{array}$ & $\begin{array}{c}\text { Enterpri } \\
\text { se scale }\end{array}$ & $\begin{array}{c}\text { Local } \\
\text { market }\end{array}$ & $\begin{array}{c}\text { Domestic } \\
\text { market }\end{array}$ \\
\hline $\begin{array}{c}\text { Zhongguanc } \\
\text { un }\end{array}$ & 307370 & 5.7188 & 29 & 15720 & $\begin{array}{c}101391 \\
0\end{array}$ & 2077 & 3906 \\
\hline $\begin{array}{c}\text { Wuhan } \\
\text { Donghu }\end{array}$ & 83755 & 0.360 & 17 & 2468 & 118563 & 277 & 3906 \\
\hline $\begin{array}{c}\text { Wuxi New } \\
\text { Zone }\end{array}$ & 33956 & 0.917 & 13 & 1021 & 297672 & 577 & 3906 \\
\hline $\begin{array}{c}\text { Fuzhou } \\
\text { Hi-tech Zone }\end{array}$ & 18987 & 0.092 & 9 & 288 & 291619 & 54 & 3906 \\
\hline & $\begin{array}{c}\text { Technical } \\
\text { standard }\end{array}$ & Planning & $\begin{array}{c}\text { R\&D } \\
\text { institute }\end{array}$ & $\begin{array}{c}\text { Association/ } \\
\text { alliance }\end{array}$ & Total revenue & Net profit \\
\hline $\begin{array}{c}\text { Zhongguanc } \\
\text { un }\end{array}$ & 1096 & 10 & 323 & 65 & 1593866575 & 110637253 \\
\hline $\begin{array}{c}\text { Wuhan } \\
\text { Donghu }\end{array}$ & 10 & 1 & 131 & 11 & 292614195 & 17667077 \\
\hline $\begin{array}{c}\text { Wuxi New } \\
\text { Zone }\end{array}$ & 101 & 10 & 87 & 8 & 303923610 & 20743716 \\
\hline $\begin{array}{c}\text { Furhou } \\
\text { Hi-tech Zone }\end{array}$ & 5 & 1 & 48 & 3 & 83986381 & 3002729 \\
\hline
\end{tabular}

Notes: 1. the number of incubator is the total number of incubator of national technical enterprises and productivity promotion center. 2 . Enterprise scale=total revenue/number of enterprise. 3. It is supposed that each of the industrial clusters is faced with the same domestic market, and the turnover of each of the industrial cluster in domestic market is the same. 4. Technical standard includes customized international, national and industrial standards. 5. If the industrial planning about the development of internet of things is set, the score will be 10 , or the score will be 1 .

2. Based on the evaluation of the main factors (the net profit will be the reference sequence) influencing the competitiveness of the industrial cluster of internet of things in Zhongguancun, Wuhan Donghu, Wuxi New Zone and Fuzhou Hi-tech Zone, the initial value will be calculated. On the basis of the original data above, the various values of Zhongguancun shall be the reference value 100 , thus getting the value of other industrial clusters in Table 5.

Table 5 Initial value of factors influencing the competitiveness of industrial cluster based on G2EM-CI model

\begin{tabular}{cccccccc}
\hline $\begin{array}{c}\text { Industrial } \\
\text { cluster }\end{array}$ & $\begin{array}{c}\text { Technical } \\
\text { talent }\end{array}$ & $\begin{array}{c}\text { Authorized } \\
\text { patent }\end{array}$ & Incubator & $\begin{array}{c}\text { Number of } \\
\text { enterprise }\end{array}$ & $\begin{array}{c}\text { Enterpri } \\
\text { se scale }\end{array}$ & $\begin{array}{c}\text { Local } \\
\text { market }\end{array}$ & $\begin{array}{c}\text { Domestic } \\
\text { market }\end{array}$ \\
\hline $\begin{array}{c}\text { Zhonggua } \\
\text { ncun }\end{array}$ & 100.00 & 100.00 & 100.00 & 100.00 & 100.00 & 100.00 & 100.00 \\
\hline $\begin{array}{c}\text { Wuhan } \\
\text { Donghu }\end{array}$ & 7.24 & 6.29 & 58.62 & 15.69 & 11.69 & 10.92 & 100.00 \\
\hline $\begin{array}{c}\text { Wuxi New } \\
\text { Zone }\end{array}$ & 11.04 & 16.03 & 44.82 & 6.49 & 29.35 & 27.78 & 100.00 \\
\hline $\begin{array}{c}\text { Fuzhou } \\
\text { Hi-tech } \\
\text { Zone }\end{array}$ & 6.17 & 1.60 & 31.03 & 1.83 & 28.76 & 2.59 & 100.00 \\
\hline \multicolumn{1}{c}{ Technical } & Planning & $\begin{array}{c}\text { R\&D } \\
\text { institute }\end{array}$ & $\begin{array}{c}\text { Total } \\
\text { revenue }\end{array}$ & $\begin{array}{c}\text { Association/all } \\
\text { iance }\end{array}$ & Net profit \\
\hline $\begin{array}{c}\text { Zhonggua } \\
\text { ncun }\end{array}$ & 100.00 & 100.00 & 100.00 & 100.00 & 100.00 & 100.00 \\
\hline $\begin{array}{c}\text { Wuhan } \\
\text { Donghu }\end{array}$ & 0.91 & 10.00 & 40.55 & 18.35 & 16.92 & 15.96 \\
\hline $\begin{array}{c}\text { Wuxi New } \\
\text { Zone }\end{array}$ & 9.21 & 100.00 & 26.93 & 19.06 & 12.30 & 18.74 \\
\hline $\begin{array}{c}\text { Fuzhou } \\
\text { Hi-tech } \\
\text { Zone }\end{array}$ & 0.45 & 10.00 & 14.86 & 5.26 & 4.61 & 2.71 \\
\hline
\end{tabular}

The gray correlation tree between factors influencing the competitiveness of industrial cluster based on G2EM-CI model and net profit. The correlation coefficient of the factors for the total revenue is calculated. The absolute value of the maximum value in difference sequence above is 94.74 while the absolute value of the minimum value is 0 , the difference is great so 0.3 is collected to calculate the correlation coefficient to reduce the influence of the great difference on the evaluation. Please refer to Table 5.12.

Table 6 Correlation coefficient between factors influencing the competitiveness of industrial cluster based on G2EM-CI model and total revenue 


\begin{tabular}{ccccccc}
\hline Industrial cluster & $\begin{array}{c}\text { Technical } \\
\text { talent }\end{array}$ & $\begin{array}{c}\text { Authorized } \\
\text { patent }\end{array}$ & Incubator & $\begin{array}{c}\text { Number of } \\
\text { enterprise }\end{array}$ & $\begin{array}{c}\text { Enterprise } \\
\text { scale }\end{array}$ & $\begin{array}{c}\text { Local } \\
\text { market }\end{array}$ \\
\hline Zhongguancun & 1 & 1 & 1 & 1 & 1 & 1 \\
\hline Wuhan Donghu & 0.761 & 0.702 & 0.413 & 0.914 & 0.810 & 0.792 \\
\hline Wuxi New Zone & 0.779 & 0.895 & 0.524 & 0.693 & 0.734 & 0.765 \\
\hline $\begin{array}{c}\text { Fuzhou Hi-tech } \\
\text { Zone }\end{array}$ & 0.968 & 0.885 & 0.524 & 0.685 & 0.547 & 0.914 \\
\hline $\begin{array}{c}\text { Domestic } \\
\text { market }\end{array}$ & $\begin{array}{c}\text { Technical } \\
\text { standard }\end{array}$ & Planning & $\begin{array}{c}\text { R\&D } \\
\text { institute }\end{array}$ & Association/alliance \\
\hline Zhongguancun & 1 & 1 & 1 & 1 & 1 \\
\hline Wuhan Donghu & 0.258 & 0.619 & 0.772 & 0.561 & 0.952 \\
\hline Wuxi New Zone & 0.259 & 0.742 & 0.259 & 0.783 & 0.807 \\
\hline $\begin{array}{c}\text { Fuzhou Hi-tech } \\
\text { Zone }\end{array}$ & 0.230 & 0.855 & 0.857 & 0.747 & 0.977 \\
\hline
\end{tabular}

For the calculation of the correlation of factors, please refer to Table 7 .

Table 7 Correlation between the factors influencing the competitiveness of industrial cluster based on G2EM-CI model and total revenue

\begin{tabular}{|c|c|c|c|c|c|c|c|c|c|c|c|}
\hline rs & $\begin{array}{c}\text { Techn } \\
\text { ical } \\
\text { talent }\end{array}$ & tent & $\begin{array}{l}\text { Incuba } \\
\text { tor }\end{array}$ & $\begin{array}{c}\text { Numb } \\
\text { er of } \\
\text { enterp } \\
\text { rise }\end{array}$ & $\begin{array}{c}\text { Enterp } \\
\text { rise } \\
\text { scale }\end{array}$ & $\begin{array}{l}\text { Local } \\
\text { marke } \\
t\end{array}$ & $\begin{array}{c}\text { Foreig } \\
n \\
\text { marke } \\
t \\
\end{array}$ & $\begin{array}{c}\text { Techn } \\
\text { ical } \\
\text { standa } \\
\text { rd } \\
\end{array}$ & $\begin{array}{c}\text { Planni } \\
\text { ng }\end{array}$ & $\begin{array}{c}\text { R\&D } \\
\text { institu } \\
\text { te }\end{array}$ & $\begin{array}{l}\text { lssoci } \\
\text { tion/a } \\
\text { iance }\end{array}$ \\
\hline & 877 & 0.870 & 615 & 0.823 & 0.772 & 0.867 & 0.436 & 0.804 & 0.722 & 0.772 & .934 \\
\hline
\end{tabular}

Order of factors influencing the net profit and total revenue of the industrial cluster based on G2EM-a model

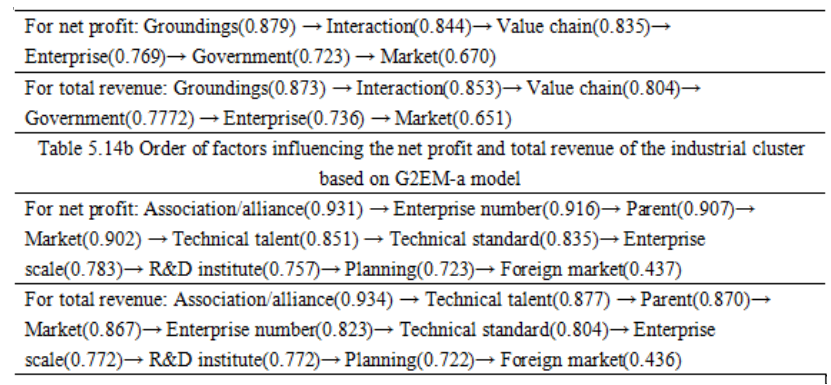

It can be seen from the evaluation above that the factors influencing the industrial cluster of internet of things are basically the same no matter the net profit or total revenue of the industrial cluster of internet of things are evaluated as the parent sequence of the evaluation of competitiveness of industrial cluster. Three factors: groundings, interaction and value chain are top three, which is of guiding significance to the cultivation of actual competitiveness of industrial cluster of internet of things.

1. Groundings are the first factor to influence the competitiveness and it shows that the knowledge resources, especially the patent and technical talents are the most critical elements to cultivate and improve the competitiveness of industrial cluster for the industrial cluster of internet of things as a hi-tech industrial cluster. Therefore, the quantity and quality of the technical talent and technical patent of internet of things should be enhanced with efforts in the process of cultivation of the competitiveness of industrial cluster of internet of things.

2. Improving the value chain of internet of things is the basic way to cultivating the competitiveness of the industrial cluster and governing the industrial cluster of internet of things. The industries in China, especially hitech industry have been locked in the lower end of value chain for a long time and located in the bottom of "smiling curve", and therefore, Chinese enterprises can just earn a few profits and most of values are carved up by R\&D and design enterprises on both sides of the value chain. It is the only choice to walk out of the "lock" to try to improve the R\&D and design ability of Chinese enterprises and adopts the high-end technology.

3. Pay attention to the expansion of local market and further improve the volume of local market. The larger the local market is in the industrial cluster and the more the manufacturers communicate and cooperate, the more intensive the corresponding technical innovation network is. Therefore, the local market has a geological advantage over the foreign market in the cultivation and improvement of the competitiveness of industrial cluster. The industrial chain of internet of thing is long and the involved industries are more, thus the government can guide the enterprises of internet of things to gather together in location through preferential policy, subsidy and special funds, etc. on the basis of existing industrial cluster of internet of things or prepared cluster, thus making the local market of internet of things stronger.

\section{References}

[1] Zou Xianhong and Yang Tao, Research on Hi-tech Industrial Competitiveness Based on Effect of Industrial Cluster [J], Technical Progress and Countermeasure, 2012 (4): 65-69

[2] Ma Xiangyang, Yin Xinyue and Chen Weidong, Research on Evaluation of Hi-tech Industrial Competitiveness Based on Passive Coordinative Mechanism- In the Case of Tianjin [J], Science \& Technology and Economy, 2013 (10): 42-47

[3] Chen Hongchuan, Empirical Research on Evaluation of Hi-tech Industrial Competitiveness [J], 2012 (8): 21-29 
[4] Zhang Xianfu, Liu Dengyu and Zhou Binggen, Research on Hi-tech Industrial Competitiveness Based on the Theory of Dissipative Structure-In the Case of Anhui Province in Central China [J], Resource Development and Market, 2013(6): 517-520

[5] Fang Yi and $\mathrm{Xu}$ Guangrui, Evaluation on Hi-tech Industrial Competitiveness in Chinese Regions [J], Science and Technology Forum of China, 2012 ( 5): 6973

[6] Xu Guangrui, Hi-tech Industrial Cluster and Industrial Competitiveness in China [J], 2013 (8): 47-52 